Крамаренко Анна Віталіївна аспірант кафедри світового господарства $i$ міжнародних економічних відносин Інституту міжнародних відносин Київського наџіонального університету імені Тараса Шевченка

\title{
ДЕРЖАВНО КЕРОВАНІ ІННОВАЦІЙНІ ПРОЦЕСИ В АСЕАН
}

Анотація. У сучасному середовищі світових економічних процесів інновачійний аспект займае ключову роль $у$ питаннях конкурентоспроможності краӥн. Національна інноваџійна система $i$ акцент на розвиток нової інновачійної економіки країн регіону $\epsilon$ факторами економічного успіху крайн в міжнародних інтегращиійних об'єднаннях.

Ключові слова: глобальні інновачійні мережі, національні інноваџійні системи, міжнародні інтеграиійні об’єднання, інноваџійний процес, інноваційна економіка.

АСЕАН - це політична і економічна міжнародна субрегіональна організація, асоціація держав Південно-Східної Азії, яка була заснована 8 серпня 1967 року в м. Бангкок, серед перших держав-членів були Індонезія, Малайзія, Сінгапур, Тайланд і Філіпіни, а в 1984 році приєдналась Бруней-Даруссалам, В’етнам в 1995 році, в 1997 році Лаос і Мьянма і Камбоджа в 1999 році.

До основних цілей Бангкокської декларації слід віднести сприяння розвитку соціально-економічного та культурного співробітництва державчленів організації і підтримання мирного і стабільного положення в Південно-Східної Азії. 
Це регіональне угруповання с самого часу появи охарактеризувало себе як одно з самих динамічно розвинених субрегіонів світу з дуже високими темпами економічного зростання. АСЕАН, сприймає всі виклики світових економічних процесів, беруть чіткий курс інноваційного розвитку 3 метою входження в глобальне виробництво з гострою необхідністю вирішення питань інтеграційних взаємодій.

Серед першочергових питань, які організація поставила на меті це формування зони вільної торгівлі та зони інвестицій, створення розгорнутої економічної інфраструктури та єдиної валюти і запровадження особливої структури управління.

Вищим органом ACEAH $є$ зустрічі глав держав і урядів, а керуючим i координуючим органом асоціації $є$ щорічні наради міністрів закордонних справ, де поточне керування відбувається Постійним комітетом під наглядом міністра закордонних справ держави. В місті Джакарта функціонує постійний Секретаріат на чолі з Генеральним секретарем.

Юридичною базою функціонування АСЕАН є договір о дружбі та співробітництві в південно-східної Азії під назвою Балійський договір 1976 року. Головним документом, що окреслює базисні політичні i економічні орієнтири є прийнята на 5-му саміті АCЕАН в 1997 році програма розвитку АСЕАН до 2020 року під назвою «Партнерство у динамічному розвитку»

В АСЕАН існує 11 спеціалізованих комітетів основною задачею яких $€$ прискорення економічного росту та розвитку регіону в соціальному i культурному аспекті.

ACEAН, як активне регіональне угруповання країн Південно-Східної Азії, має на меті такі ряди завдань:

- Формування зони вільної торгівлі

- Впровадження єдиної валюти

- Створення зони інвестицій 
- Формування розгорнутої економічної інфраструктури

- Встановлення спеціальної структури керування.

АСЕАН не має тенденцій до внутрішнього кількісного розширення учасників-членів і не дивлячись на велику кількість заявок, відкривати свої двері для всіх бажаючих не вважає за вірне. Діє тимчасовий мораторій на надання іншим державам статусу партнера по діалогу с АСЕАН. Наразі концентрування на концепції редагування механізму «постміністерських конференцій», що діють в форматі «10+1» - тобто, АСЕАН веде діалог 3 кожним партнером.

На 7 саміті ACEAН у Брунеї підняли питання розвитку інформаційно-комунікаційних технологій у країнах дійсного регіону i визначили необхідність подолання електронно-цифрового розриву на території всіх країн АСЕАН і це відбувалось через різні рівні освіти, доходів і соціального, економічного положення, а також високий рівень бідності населення і збільшення рівня соціальних диспропорцій i ,як наслідок, науково-технічна відсталість економічно менш розвинених країн.

Програма ліквідації «цифрового розриву» передбачає співробітництво національних органів управління інформаційнокомунікаційними системами, підтримка взаємної торгівлі і інвестицій галузі, залучення приватного сектору і розробку і прийняття стандартів для цієї системи з метою забезпечення відповідності в рамках АCЕАН, створення електронної платформи АСЕАН i проведення онлайн конференцій в рамках держав регіону. [

На 9 саміті АCЕАН в 2003 році була ухвалена концепція «співтовариства АСЕАН», що мала на меті створення спочатку до 2020, а потім цей термін перенесли до 2015 року три типи співтовариства співтовариство політики і безпеки, соціально-культурне співтовариство і економічне співтовариство. Основною задачею було забезпечити вільний рух товарів і послуг, робочої сили кваліфікованого зразка, та лібералізація 
руху капіталу i інвестицій. Цей проект отримав назву «В’єнтьянська програма дій» [10].

Також, серед основних цілей АСЕАН було стабілізувати військовополітичний стан і сформувати митний союз. Але до початку 1990-х років вдалось лише сформувати зону преференційної торгівлі. Преференційна торгівля - це торгові відносини між декількома країнами 3 метою спрощення міжнародної торгівлі через зниження внутрішніх тарифів на одні й ті ж самі товари, не на всі одразу. Зона преференційної торгівлі $є$ першим етапом економічної інтеграції і має на меті стати зоною вільної торгівлі. В АСЕАН не існує чітких строків процедури митного зниження чи позбавлення, все залежить виключно від рівня економічного розвитку країни-учасника.

Підвищення рівня економічного розвитку країн-учасників АСЕАН дало поштовх до реальних інтеграційних процесів в 1990-х роках і це сприяло створенню зони вільної торгівлі АФТА ${ }^{1}$ в 1992 році рішенням Сінгапурського саміту. Задля підвищення конкурентоспроможності товарів, що вироблені в АСЕАН необхідним було знати інноваційні форми промислового співробітництва i, як наслідок, 27 квітня 1996 року було підписано базову угоду за схемою промислового співробітництва АСЕАН $(\mathrm{AIKO})^{2}$. Наступним кроком стало підписання в жовтні 1998 року рамкової угоди про створення зони інвестицій АCEAH (AIA) ${ }^{3}$, що є головним інструментом залучення інвестицій внутрішнього і зовнішнього характеру.

Інструментом реалізації АФТА була угода підписана в 1992 році про спільний преференційний тариф. Поступово почалось розширення диверсифікації товарів, що попадали у процес тарифної лібералізації, а наразі майже всі торгові процеси між країнами-членами є безмитними.

\footnotetext{
${ }^{1}$ ASEAN Free Trade Area - AФTA - набуло чинності в січні 1993 року.

2 AICO - ASEAN Industrial Cooperation - AIKO (укр.) заснована 27 квітня 1996 року в Сiінгапурі.

${ }^{3}$ ASEAN Investment Area - зона інвестицій ACEAH, 1998 рік.
} 
Основними цілями під час створення зони вільної торгівлі були створення сприятливих умов для торгівлі товарами і послугами всередині асоціації, підвищити конкурентоспроможність економік своїх країн i стимулювати розширення субрегіонального товарообігу.

Також на меті є залучення до економічного співробітництва країн регіону з низькими показниками економічного розвитку Південно-Східної Aзii.

Основним інструментом реалізації зони вільної торгівлі $є$ Угода про спільний преференційний тариф (СЕПТ) ${ }^{4}$, що була підписана в Сінгапурі в 1992 році країнами-членами АСЕАН. Згідно стандартів функціонування СЕПТ, існує розмежування товарів на чотири категорії:

- Товари, рівень тарифікації на яких підлягає скороченню згідно 3 пришвидшеним або стандартним графіком і до цієї групи відносять 88\% всіх товарів приналежності АСЕАН.

- Товари, що підлягають вилученню і грають важливу роль у забезпеченні інтересів національної безпеки, захисту життя, моралі і здоров'я людей та оточення, художні, історичні і археологічні цінності.

- Товари, що підлягають вилученню і країни-члени АСЕАН вважають зниження тарифів на ці товари передчасними через вплив внутрішньо економічних факторів, але передбачають поступове скорочення кількості цих товарів.

- До четвертої категорії належить сільськогосподарська сировина, що було першочергово виключено з зони вільної торгівлі.

На сьогоднішній день, більше ніж 99\% товарів шести країн-членів ACEAН ( Бруней-Даруссалам, Індонезія, Малайзія, Філіпіни, Сінгапур і Тайланд),що включені в список СЕПТ, досягли зниження до тарифного діапазону $0-5 \%$.

${ }^{4}$ CEPT - Common Effective Preferential Tariff. 
В 2004 році задля покращення організаційно-правової бази діяльності АСЕАН було ухвалено рішення о розробці статуту АСЕАН і був підписаний на 13-м саміті у Сінгапурі лідерами асоціації. Це слугувало новим початком трансформації асоціації у повноцінну регіональну організацію і набув чинності в грудні 2008 року.

Основним органом управління, що відповідає за реалізацію структури СЕПТ $є$ рада АФТА, до якої відносять міністрів економіки держав-членів і Генеральний секретар АСЕАН. Допоміжною потужністю є регулярні зустрічі вищих економічних посадовців і Секретаріату АCEAH, які здійснюють поточну регуляцію домовленостей.

Інноваційний підхід в регіоні АСЕАН, тобто Південно-Східної Азії дуже специфічний, від не відзначається дуже фундаментальними науковими розробками, центрами концентрування знань у порівнянні 3 такими гігантами, як США і $\mathrm{CC}$, але АCЕАН розвиваючи інноваційну інфраструктуру шляхом надання широко спектру преференцій, залучає у свій регіон великі ТНК і зацікавлені державні представництва задля розміщення виробничих потужностей і наукових центрів і таким чином сприяючи розвитку національного інноваційного потенціалу державучасників.

Основним напрямом взаємодії країн регіону Південно-Східної Азії 3 країнами, що розвиваються у сфері зовнішньо-торгівельних відносин $є$ зміцнення і розширення внутрішньо-регіональних зовнішньо-торгівельних відносин в рамках АСЕАН. Враховуючи зростаючу конкуренцію промислово розвинених країн і країн, що розвиваються, таких як Індія $і$ Китай, прогрес країн Південно-Східної Азії в сфері взаємного торгівельноекономічного співробітництва випереджає динаміку зовнішньоторгівельних зв'язків в цілому. Обсяг внутрішньо-регіональної торгівлі в період з 1993-2010 років збільшився у 6,3 разів, а загальна експортна торгівля збільшила свої показники у 4,8 разів. Частка взаємної торгівлі 
країн в експортних операціях збільшилась на 3,9 п.п. і в імпортних на 8,4 п.п. Це вплинуло на питому вагу внутрішньо-регіонального експорту в експортній торгівлі країн цього регіону на 2010 рік досягнув 25\%, а імпорт у всіх операціях $-25,8 \%$.

Основна особливість моделі економічного розвитку країн АСЕАН полягає у ролі держави в якості координатора, коли розуміння «держава приватний бізнес» відбувається не лише на рівні країни, а й на регіональному рівні. Платформою для реалізації цих координацій є Ділова консультативна рада $\mathrm{ACEAH}^{5}$ основною метою якої $є$ консультативна підтримка бізнес-проектів, що відбуваються в регіоні АСЕАН і це дуже схоже на принцип дії $€$ с стосовно бізнес i інноваційного сектору i фінальною метою яких є підвищення інвестиційної привабливості країн та регіонів у розумінні єдиної цілісної мережі АСЕАН.

Інноваційна модель АСЕАН викладається у Декларації АCЕАН про Інновації [11] і підтверджує важливість співпраці між державами-членами ACEAH у напряму формування спільноти АCEAН, що $є$ політично згуртованою, економічно інтегрованою і соціально відповідальною. ACEAН у Декларації визнає важливість науки, а також роль технологій і інновацій у сприянні сталого економічного зростання, створенню робочих місць і посиленню систем науки та інновацій, що є основою для зростання конкурентоспроможності галузей у регіонах. Ця діяльність відбувається в рамках АCЕАН Плану дії у галузі науки, технологій і інновацій APASTI 6 , що передбачає ряд стратегічних питань, що зосереджені на державноприватному співробітництві, мобільності талантів і взаємної співпраці.

У Декларації зазначені необхідні політичні заходи, які сприяють досконалості та актуальності і заохочує створенню тісних зв'язків між

\footnotetext{
${ }^{5}$ ASEAN Business Advisory Council - ACEAН БАК Ділова консультативна рада ACEAH.

${ }^{6}$ APASTI - план дій ACEAH щодо розвитку науки, технологій і інновацій в рамках програми ASEAN Community 2025, терміном дії з 2016 - 2025 роки.
} 
урядом, науковими колами і промисловістю та суспільством 3 метою посилення впливу науково-технічних інновацій. До них відносяться: [13]

- Визнання можливостей і переваг інноваційних стартапів і рушійних технологій, які дозволяють трансформувати всі сектори суспільства i це вимагає цілісної політики, яка сприятиме підприємницької діяльності і створенню нових бізнес-середовищ, провокувати рух капіталу і здатність використовувати масштаби ринку регіону ACEAH;

- Підтримка і винагородження інноваційних фірм та підприємств, які створюють можливості для плацевлаштування шляхом співпраці, капітальних інвестицій та транскордонних операцій за допомогою цифрових технологій;

- Стимулювання розвитку інноваційної грамотності, а також постійний розвиток загальних, спеціалізованих i додаткових навичок у науці, технічних розробках, математиці і інформаційнокомунікаційних технологіях, задля забезпечення робочу силу навичками і компетенціями для ведення інноваційної діяльності через освіту і політику підготовки спеціалістів;

- Посилення політики і регуляторного середовища для мікро-, малих i середніх підприємств, що сприяє розвитку міждержавних механізмів співпраці та координації, залучення цих підприємств до співпраці $з$ метою вироблення політики захисту інтересів підприємців і здешевлення процесів формування бізнесу i підприємницької діяльності;

- Створення сприятливої і динамічної внутрішньої політики АСЕАН для інноваційних досліджень та процесів передачі технологій. Розширити підтримку фіскальної та нефінансової політики інноваційних досліджень в усіх підприємствах регіону АСЕАН; 
- Використання науково-дослідних інновацій у реалізації цілей сталого розвитку ООН шляхом сприяння подальшого використання розробок для вирішення глобальних і соціальних проблем;

- Заохочення створенню регіональних мереж спільних досліджень, ініціатив розбудови потенціалу і інновацій, що зосереджені на тематики АСЕАН і сприяють посиленню співпраці з глобальними партнерами через мережеві організації;

- Розвиток прав інтелектуальної власності і систем їх регулювання задля налагодження наукового співробітництва, комерціалізації технологій і розвитку інноваційної культури. [11]

При розгляді даних щодо інноваційної діяльності у АСЕАН слід розглянути основні показники розвитку інновацій в країнах. У таблиці нижче представлено інтенсивність НДДКР на ВВП для асоційованих членів ACEAH i за винятком Сінгапуру, вони мають низьку частку інвестицій в НДДКР відносно ВВП. Тенденція витрат на НДДКР в Малайзії швидко зростала.

Таблиия 1

\section{Витрати на НДДКР}

\begin{tabular}{|l|l|l|l|l|}
\hline & 2011 & 2012 & 2013 & 2014 \\
\hline Індонезія & - & - & 0,08 & - \\
\hline Малайзія & 1,03 & 1,09 & - & 1,26 \\
\hline Мьянма & - & - & - & - \\
\hline Філіпіни & 0,12 & - & 0,14 & - \\
\hline Сінгапур & 2,15 & 2,00 & 2,00 & 2,19 \\
\hline Тайланд & 0,36 & - & - & 0,48 \\
\hline Вьетнам & 0,19 & - & - & - \\
\hline
\end{tabular}

Джерело: UNESCO Institute for Statistics [12]

Переходячи на конкретизацію інноваційного штампу країн-учасників асоціації, слід виділити таку високо розвинену країну, як Сінгапур. Сінгапур задає високі стандарти і грає роль гарного прикладу для інших країн асоціації, як економічно і інноваційно розвинена система. Такі 
країни, як Індонезія, Філіппіни, В’єтнам і Таїланд мають проблеми 3 потужними обмеженнями попиту через значні негативні показники безробіття і рівня бідності населення. Щодо Малайзії, то країні вдалось знизити показники безробіття і бідності.

Це вдалося шляхом орієнтації на відкриту політику інноваційного погляду економіки i експортно-орієнтовану структуру. Державні регуляторні програми розвитку Малайзійської економіки 32010 року націлені на будування «Нової Економічної Моделі» ${ }^{7}$, що має на меті реалізацію концепції інноваційної економіки. Основні цілі і задачі моделі не є досить кардинальними і мають дуже м’який підхід.

Принципи Нової Економічної Моделі - це лінія послідовних дій уряду в напряму розвитку Малайзії 3 вже існуючих інноваційних орієнтирів. Ця модель створена завдяки реалізації програми економічних перетворень в рамках концепції розвитку країни до 2020 року.

В межах державного і приватного партнерства Малайзії в 1996 році розпочалося створення «Мультимедійного Супер Коридору» ${ }^{8}$, і стало складовою частиною моделі. Перші три роки будівництва відносилися до питання лише державного інвестування в розмірі 2,4 млр. малайзійських ринггітів, а наступні 10 років інвестування перейшли на компанію Telekom Malaysia в розмірі 8,9 млрд. ринггітів. В 2010 році цей проект було запущено і стало основою для перетворення економіки Малайзії у регіонального і глобального лідера у сфері розвитку інформаційнокомунікаційних технологій.

Розвиток Мультимедійного Супер Коридору передбачав будування кіберцентрів - Кіберджая, Путраджая, бізнес-інкубатори MTDC, KL Tower, KLCC у Куала-Лумпурі i Технологічний парк Малайзії. Де Путраджая i

7 «Нова Економічна Модель Малайзії» створена в 2010 році під керівництвом прем’єр міністра Дато Шрі Мохд Наджиб бін Тун Абдул Разак і є структурним елементом концепції розвитку країни до 2020 року.

8 Мультимедійний Супер Коридор» - це високошвидкісна мережа широкосмугового зв'язку з швидкістю передачі даних від 10 Мбіт/с до 100 Мбіт/с. 
Кіберджая це нові міста, адміністративні центри федерального уряду, 3 розвиненою структурою IКТ компаній, що орієнтовані на створення інноваційного продукту.

Серед основних цілей і пріоритетів функціонування IКТ компаній слід виділити такі:

- Розвиток концепції «розумної освіти»

- Розробка та впровадження багатоцільової картки з мікропроцесором

- Ідея розробки і реалізації концепції електронного уряду,

- Створення глобальної мережі виробників,

- Трансграничний маркетинг,

- Питання розвитку мультимедійної медицини.

Для залучення та підтримки зацікавлених міжнародних компаній, МСК використовує розгалужену систему оптоволоконного кабелю, як шляху прямого зв’язку Малайзії з іншими країнами АСЕАН, США, Японіï і Свропи. Компанії в свою чергу отримують сучасну транспортну систему, соціальну інфраструктуру і нефіскальні і фіскальні пільги тому, що під час підготовки проекту МСК відбувались зрушення нормативно-правового аспекту.

В 1997 році прийняли чотири закони о кіберпросторі - закон о електронно-цифровому підпису, як додаток до закону о авторському праві, закон про злочин з використанням технічного обладнання i закон щодо мультимедійної медицини.

Це все є невід’ємною частиною нової політики щодо реалізації концепції інноваційної економіки, що базується на економіки знань. Однією з головних передумов нового підходу є новий рівень конкурентної гонки між державами за інвестиційний капітал шляхом поступового спрощення нормативно-правового режиму. Компаніям-резидентом пропонували п’яти річні «канікули» від виплат податку на прибуток 3 можливістю пролонгування до 10 років, відсутність митного збору на 
імпортоване мультимедійне обладнання і надання грантів малим і середнім підприємствам-резидентам на наукові розробки і дослідження. Більш того, уряд стимулював залучення висококваліфікованих трудових ресурсів 3 інших країн без будь-яких обмежень і дозволив компаніям мати як частково, так і повністю іноземний капітал 3 вільним вивезенням i завезенням іноземної валюти.

В свою чергу, для того щоб отримати всі ці пільги компанії повинні відповідати ряду вимог:

- Бути виробником або великим споживачем мультимедійних продуктів та послуг,

- Мати можливість працевлаштувати велику кількість висококваліфікованого персоналу,

- Довести як саме компанія збирається залучати технології або знання в економічну систему Малайзії або стимулювати цей розвиток саме в країні.

В 2004 році інноваційний процес набирає оберти і з'являються нові «кіберміста» Байан Лепас (штат Пенанг), парк високих технологій Кулім (штат Кедах) і кіберцентри - штат Перак, Паханг, Негрі Сембілан і Джохор.

Серед завдань інноваційної політики виділяється підтримка МСК, як центру світового розвитку інформаційно-комунікаційних технологій i розповсюдження досягнень цього регіону по країні загалом з метою впровадження передових технологій в економіку Малайзії.

В рамках концепції розвитку інноваційної економіки Малайзії до 2020 року відбувається удосконалення розповсюдження інформаційнокомунікаційних технологій шляхом відбудування широкої мережі «кіберміст» по всієї країні задля досягнення загальної мети - створення економіки знань. 
Повертаючись до лідера економічного розвитку серед країн АCЕАН, Сінгапуру, слід зазначити, що Сінгапурська інноваційна модель теж мала досить поступовий характер. Спочатку були створені інститути, а потім механізми функціонування цих інститутів. Але нажаль відкриття в 1980 році Наукового парку не було ефективним і результативним, як в практиці інших держав через нездатність економічної і законодавчої системи зріло регулювати ці нововведення. Сама система і організації, що займаються інноваціями і які входять в цю систему не були готові.

В той час, створення Агентства $з$ технологій, науки і досліджень дало початок напрацюванню стратегій з розвитку інновацій і стало причиною створення Ради з стандартів, потужності і інновацій.

Формування Сінгапурської інноваційної моделі розвитку $\epsilon$ унікальним так, як модель була сформована в трьох етно-конфесійних громадах - китайської, малайської і індійської, але й під впливом спадщини британського колоніального правління. Активне втручання держави в процес формування інноваційної бази є також характерною особливістю Сінгапурського підходу, що успішно відбувалось завдяки використанню державних важелів економічного стимулювання i регулювання процесів. На державному рівні плануванням і питаннями розвитку інноваційної інфраструктури займався Комітет Економічного Розвитку. В обов'язки якого входило планування високовартісних капіталомістких підприємств зв'язку і транспорту, доріг і портів, а також електромереж, водопровідних систем i регулювання підготовки кваліфікованих кадрів. Питання кваліфікованих кадрів це завжди першочергове питання на шляху успіху чи то компанії, чи то держави, тому Сінгапур вирішив це збільшивши витрати на освіту з 2,8\% ВВП у 1980 році до показника 4,1\% в 1995 році. Вся освітня програма була модернізована с середини $80-x$ років і підлаштована під особливо необхідний попит на випускників технічних спеціальностей. 
Створення державного комітету національної комп’ютерізації задля контролювання і впровадження прийнятих урядом заходів щодо розвитку IT сектору і запровадження Національного технічного інституту в 1981 році стало рушійною силою нової інноваційної моделі. Взагалі 80-ті роки стали засновницькими в галузі запровадження інформаційних технологій на терені всієї країни, і перш за все комп’ютерізацією урядових структур. Комітет національної комп’ютерізації займався впровадженням IT в урядові ланки і підвищенням рівня технічної освіти серед загальних прошарків населення.

Як наслідок, в 1986 році уряд Сінгапуру розробив Національний технологічний план, який став першим кроком назустріч майбутньому. В рамках цього плану був впроваджений електронний обмін даними, що слугував зв’язком між урядовими системами і промисловістю в цілому, це дало змогу створити інноваційну електронну мережу під назвою IDNet. Ця мережа поєднала державні інститути і дала змогу вивести всю звітність в електронний формат.

Наступним кроком стало формування сприятливої платформи для функціонування інноваційної системи, а саме згідно національного технологічного плану створено фонд, що займається підтримкою НДДКР загальним обсягом 2 млрд. дол. і запропонуванням грантової системи і податкової пільги для швидкого стимулювання НДДКР.

Вищезгадане Національне комп'ютерне управління в 1999 році продовжило своє функціонування під модернізованою назвою Управління 3 розвитку інформаційно-комунікаційних технологій. Глобалізаційні процеси світу знову не залишили осторонь Сінгапурське державне регулювання.

Але найцікавішим є те, що законодавство стосовно інформаційних технологій Сінгапуру засновано на державному праві Британської імперії, тобто держава виступає регулятором інноваційних процесів i веде 
інноваційну політику шляхом реалізації федеральних цільових програм, моделей оптимізації економічних процесів і балансів, а також державних замовлень і контрактів.

Сутність Сінгапурської інноваційної моделі полягає у державному сприянні приватному бізнесу шляхом розосередження підприємств в різних промислових регіонах задля залучення нових технологій i опанування нових сфер підприємницької діяльності.

Першим кроком до програми «Інноваційний кластер» стала державна програма розвитку інновацій, досліджень і підприємництва. Надалі всі програми та інноваційні плани, які задавали нові вектори розвитку економіки країни формувалися на основі цієї програми.

До основних завдань програми розвитку інновацій відносяться:

- Комерціалізація інноваційних розробок дослідницьких лабораторій шляхом створення стартап-компаній;

- Підтримка в університетах і технічних учбових закладах розвитку наукового потенціалу задля перетворення результатів дослідницької діяльності у комерційні продукти, що здатні конкурувати на ринку.

Щодо політики розвитку стартапів, то успішне їх впровадження, а після функціонування відбувається завдяки державної політики податкових пільг.

Згадуючи ще одну країну АСЕАН, В’єтнам, слід зазначити, що ця країна грала велику роль у процесах регіональної інтеграції. В’єтнам завжди мав великий вплив на АСЕАН, починаючи 3 моменту створення асоціації у 1967 році ще без включення В’єтнаму і в 1995 році, коли приєдналась до рядів членів, будучи центром впливу серед країн Індокитаю. Це приєднання стало великим кроком для регіональних інтеграційних процесів і становлення регіону Південно-Східної Азії політико і економічно цілісним. 
В’єтнам мав певні очікування від цього союзу в питаннях використання асоціації як мережі країн з високим рівнем технологічного розвитку задля власної індустріалізації і модернізації та розраховували на укріплення своїх геоекономічних і геополітичних позицій.

Основним завданням уряду В’єтнаму стала боротьба за розвиток науково-технологічного потенціалу країни до 2010 року. А саме модернізація і використання ринкових методів, хоча направленість В’єтнамської економіки це ринкова економіка соціалістичної орієнтації.

Щодо ролі Індонезії в асоціації, то АСЕАН завжди розглядала Індонезію як так званого лідера 3 гнучкою демократичною системою, високою економічною продуктивністю i відносним міцним рівнем воєнного забезпечення країни. Згідно внутрішньої політики АCEAН всі держави знаходяться на рівних, а Індонезію вважають найпершою через рівних. Діяльність Індонезії спостерігається в G-209, Всесвітньої торгової організації і форумах ATEC $^{10}$.

Філіпіни є швидко зростаючим сучасним ринком в сфері електронної торгівлі регіону Південно-Східної Азії. Локальний департамент інформаційних і комунікаційних технологій створює місцеві платформи в сфері інноваційних технологій і цифрової економіки. Філіпіни прогнозують зростання обсягу електронної торгівлі на 34\% до 2025 року.

В чому полягає успіх філіпінської інноваційної спартап системи? Існує п’ять факторів, до яких належать:

- Культурна харизматична приналежність до здатності бути активним учасником підприємницької діяльності, мати зацікавленість і хист;

- Філіпіни - це країна 3 високими темпами зростання ВВП, де відсотковий приріст за рік може досягти більше 60\%;

9 G-20 - це група двадцяти міністрів фінансів та керівників центральних банків 20 економік.

10 ATEC - азійсько-тіхоокеанське економічне співробітництво. 
- Філіпіни мають на меті стати лідерами впровадження інновацій у країнах, що розвиваються завдяки сучасним цифровим системам формату mobile-only.

- Зростання інвестицій, яке спостерігається на всіх стадіях інноваційної системи міжнародними організаціями та фондами.

- Дуже розгалужена система організацій, яка підтримує стартапи локального виробництва відкритого зразку.

Наприкінці 2014 року міністерство торгівлі і промисловості Філіпін анонсувала програму розвитку електронної торгівлі в країні i спрогнозувала пришвидшений темп зростання цього сектору до 2020 року. Зростаюча конкуренція збоку сусідніх країн стала рішучим фактором розвитку взаємодії між державним і приватним сектором в шести напрямах дії:

- Інвестиції - підтримка прямих іноземних інвестицій і залученням іноземних інвесторів шляхом створення сприятливих умов;

- Інфраструктура - створення і розвиток ефективної комунікаційної інфраструктури та ланцюгів поставок;

- Інформаційні потоки - компонент цифрової економіки, що забезпечує доступ до використання, обробки і передачі інформації і зберігає ії конфіденційність;

- Інновації - створення умов для стимулювання інновацій і розвиток НДДКР;

- Інтелектуальний капітал - стимулювання розвитку висококваліфікованих кадрів шляхом здобуття навиків і вмінь як підприємницького, так і технологічного укладу;

- Інтеграція - здатність локальної промисловості інтегруватись 3 глобальною економікою. 
Інноваційна діяльність на Філіпінах набирає обертів, особливо за ініціатив державно-приватного партнерства і завдяки цьому баченню в 2015 році створили у кооперації з стартап суспільством сучасне бачення динамічної екосистеми стартапів країни, що призведе до нового кроку економічного розвитку держави. Програма, в рамках якої будуються близько 500 стартапів до 2020 року з капіталізацією у 2 млрд. доларів має назву «The Philippine Roadmap for Digital Startups». До цієї програми входять ряд заходів, які необхідні і перш за все це стимулювання велику кількість операторів зв'язку до виходу на ринок інтернет-сервісів, що в результаті призведе до зниження цін на послуги.

Наступним кроком $є$ розвиток центрів, що надають відкритий $\mathrm{i}$ простий доступ до інформації і інтернет-інфраструктурі не лише шляхом залуження партнерів приватного сектору, а й впровадження державного фінансування теж. Як і в багатьох інноваційно орієнтованих державах АCЕАН, модернізація будь-яких процесів неможлива без створення відповідної законодавчої бази регулювання, а саме спрощення ряду бюрократичних питань, оптимізація процесу відкриття інноваційних компаній і обов'язком є надання податкових пільг.

Щодо Сінгапуру, то він приділяє високу увагу ролі державних і приватних інститутів в економіки країни і це чітко простежується в положеннях програми розвитку інновацій, де стартапам, які повністю відповідають вимогам, звільняються від податків в перші три роки діяльності.

Це одним цікавим фактом підтверджуючим державний характер інноваційного розвитку Сінгапуру це то, що перша існуюча інноваційна система з'явилась державної приналежності і управління якої відбувається лише державними органами. Вже зазначена Рада 3 питань досліджень, інновацій і підприємництва регулює інноваційні питання, які потім в 
залежності від характеру діяльності переходять по різним міністерствам країни для подальшого опрацювання.

Продуктивне впровадження та реалізація інноваційного курсу відбувається завдяки активної участі держав-членів ACEAН. Вищезазначений досвід регіонів Малайзії і Сінгапуру склав чітке бачення важливості вкладу державних програм та проектів для переходу на новий інноваційний рівень економіки - це економіка знань. Лідери держав i високопосадовці 3 інших державних структур публічно просувають i обговорюють цілі та задачі інноваційних програм і проектів та регулюють всі етапи виконання програм. Тому, що курс на інноваційний розвиток неможливий без створення чіткої державної інноваційної політики, яка вже потім реалізується через систему власних програм і проектів.

Прем’єр міністр Малайзії, як все говорилось вище, був ініціатором створення Мультимедійного Супер Коридору і активно публічно захищав свою інноваційну ідею, а в Сінгапурі, прем’єр міністр започаткував нову програму економічної діяльності країни, що була націлена на економіку знань. Індонезія теж не залишилась осторонь і заявила о необхідності переходу економіки на новий вектор розвитку економіки знань, створивши концепцію «створення телематичного суспільства до 2020», де застосування інформаційних технологій $\epsilon$ основною потребою національного масштабу.

АСЕАН, як регіональне об'єднання $є$ п’ятою за величиною економікою в світі і саме тому цифрова революція так наполегливо обіймає найважливіші позиції в пріоритетах і цілях держав-учасників асоціації.

Розвиток цифрової економіки є залежним від п’яти особливих пріоритетів:

- Доступ до інтернет джерела повинен бути відкритим, доступним i досяжним для кожного; 
- Економічна політика повинна стимулювати конкуренцію i заохочувати до неї, там самим спонукаючи до інноваційності;

- Система сучасної освіти повинна модернізуватися таким чином, щоб бути здатною до підготовки висококваліфікованих кадрів для майбутньої цифрової економіки;

- Система соціального захисту населення повинна враховувати ризики різких хвиль безробітності внаслідок інноваційної автоматизації підприємств;

- Сучасна система фінансового регулювання можливих ризиків.

- АСЕАН це асоціація наповнена молодим населенням так, як більш ніж половина населення країн асоціації досягає близько 30 років. 10 країн-членів асоціації слідують шляхом посиленої економічної інтеграції і має на меті стати центром цифрових оборотів світу, але є деякі питання невирішного порядку. Це доступ до мережи, найбільші райони покриття у Брунее-Даруссаламі, Малайзії і Сінгапурі, але є такі регіони як Індонезія, Лаос, Мьянме i Камбодже, де відкрита цифрова мережа доступна лише для 30\% населення країн і це значно порушує загальну картину цифрових стрибків уперед.

До позитивних аспектів функціонування АСЕАН слід віднести напрям успішного просування регіоналізму і механізм прийняття рішень, оснований на консенсусі, що віддає пріоритет колективним інтересам над індивідуальними інтересами держав-членів. Головна риса відмінності регіоналізму в АСЕАН від ЄС є відсутність навіть ідеї наднаціональності і базується на міжурядовій основі.

Основною причиною процесів застою економічного і інноваційного розвитку вважаю першочергову мету формування АСЕАН - підтримка миру і безпеки в регіоні, а не економічне співробітництво. Щодо недоліків ведення бізнесу в країнах АСЕАН то це дисбаланс адміністративного регулювання в кожній країні і обмеження щодо залучення іноземних 
капіталів, а також диференціація національних податкових систем. Саме тому так важко казати про швидкозростаючі темпи внутрішньої торгівлі, але перспективи нарощування показників $є$ дуже амбітними. Існуючий низький рівень взаємних торгівельних зв'язків говорить про те, що економічна інтеграція в рамках АСЕАН і під егідою АФТА не бачить на меті інтенсифікацію внутрішньо регіональної торгівлі і не слід чекати значного зростання взаємного товарообігу в умовах переважного рівня експортного інтересу до інших країн таких, як США, Японія і регіон СС. Застосування безмитної торгівлі скоріше направлено на залучення іноземних інвестицій для виробництва і потім експорту товарів до країнучасниць всередині виробничих ланцюгів різноманітних ТНК, що функціонують в країнах АСЕАН.

\section{Література}

1. ASEAN Statistical Yearbook 2003, C. 56; ASEAN. External Trade Statistics. Table 18. $=$ http://aseansec.org/stat/Table18_27pdf.

2. Доклад Отдела экономического планирования при прави- тельстве Малайзии (Economic Planning Unit), 2001 г. URL: http://www.epu.gov.my

3. Доклад Отдела экономического планирования при правительстве Малайзии (Economic Planning Unit), 2005 г. URL: http://www.epu.gov.my

4. Руководство по созданию инновационных центров (технологии и закономерности) // Бюллетень Рейтингового агентства «Эксперт РА»- 19 апреля 2017 г. С.95-102.

5. Механизмы государственной поддержки инновационного предпринимательства. Под редакцией О.П. Молчановой. М., 2010 С. 18.

6. ASEAN in Davos. www.siiaonline.org, January 2007. 
7. Rasiah R. Are Electronics Firms in Malaysia Catching Up in the Technology Ladder? / R. Rasiah // Journal of Asia Pacific Economy. 2010. No15(3). P.301-319.

8. Писаренко С.М. Інноваційна основи конкурентоспроможності регіону / С.М. Писаренко // Актуальні питання підвищення конкурентоспроможності держави, бізнесу та освіти в сучасних економічних умовах; Матеріали Перша Міжнародної науково практичної конференції. Том 3. Полтава, 2013 р. С. 27-33

9. URL: http://www.asean.org.

10.Press Statement By The Chairperson Of The 9th ASEAN Summit and the 7th ASEAN + 3 Summit, Bali, Indonesia, 7 October 2003; http://www.aseansec.org/15259.htm

11.URL: https://asean.org/storage/2017/11/01-ASEAN-DECLARATIONON-INNOVATION-as-of-Oct16-Final-for-Adoption-clean....pdf

12.URL: http://uis.unesco.org/sites/default/files/documents/ip37-summaryreport-of-the-2015-uis-innovation-data-collection-2017-en.pdf

13.«АСЕАН в начале 21 века. Актуальные проблемы и персвпективы» Васильев Л. Е.; Актуальные проблемы» Российская Академия наук; Учреждение Российской академии наук. Институт Дальнего Востока РАН. Центр изучения Вьетнама и АСЕАН; Москва, ИД «Форум»; 2010 рік.

URL: http://www.ifesras.ru/attaches/books_texts/ASEAN211.pdf 